\title{
Gjesteredaktørenes innledning
}

Torjer Andreas Olsen UiT Norges arktiske universitet torjer.olsen@uit.no

Cato Christensen OsloMet - storbyuniversitetet. cato.christensen@oslomet.no 
Norge har til alle tider rommet et kulturelt, språklig og etnisk mangfold. I den offentlige samtalen er det imidlertid lett å få inntrykk av at det flerkulturelle Norge er av ganske ny dato, og at mangfoldet først kom med innvandringen over de siste 40-50 årene. Politisk anerkjennes det kontinuerlige mangfoldet gjennom at samene er gitt urfolksstatus og at jøder, kvener/norskfinner, rom, romanifolket og skogfinner er gitt status som nasjonale minoriteter.

Spørsmålet om det nye eller det langvarige mangfoldet blir av Åse Røthing (2017) tematisert som to ulike, og til dels konkurrerende, fortellinger om Norge som et mangfoldig samfunn. Den ene fortellingen legger vekt på at Norge har blitt et flerkulturelt samfunn i løpet av de siste tiårene, mens den andre fortellingen trekker opp et større bilde, som både spenner lengre tilbake i tid og synliggjør at mangfoldet omfatter mer enn bare innvandring. Selv det er denne siste, større, fortellingen som egner seg best som kunnskapsgrunnlag for en oppdatert forståelse av dagens komplekse norske samfunn, så er det fortsatt den første fortellingen som ser ut til å dominere i mediedebatter og allmennforståelsen.

Til en viss grad gjelder en form for «arbeidsdeling» $i$ akademia også, hvor de forskerne som befatter seg med diskurser om «det flerkulturelle Norge» ikke skimter så alt for mye til forskning på det Plesner, Brandal og Døving omtaler som de «gamle» minoritetene (2017), og vice versa. Muligens handler dette om faglige røtter - hvor forskningen på innvandring og integrering springer ut av migrasjonsforskning (jf. Midtbøen 2017), mens forskningen som berører problemstillinger vedrørende samene eller de nasjonale minoritetene følger andre faghistoriske spor.

For samene spesielt er det mulig å snakke om en form for adskillelse gjennom oppkomsten av urfolksstudier som eget fag- og forskningsfelt. At mye av forskningen om samer og samiske forhold faller inn under denne paraplyen, har naturligvis mye for seg. Det muliggjør blant annet det komparative blikket på ulike urfolksgrupper rundt om i verden. Ikke desto mindre kan vi også ane den konsekvensen at samene faller ut av forskningsdiskursen om mangfold i Norge.

Når FLEKS nå velger å gi ut et temanummer om samer, så er det med bakgrunn i denne typen betraktninger. FLEKS har en profil knyttet til kulturelt og språklig mangfold, til utviklingsarbeid, til det flerkulturelle og interkulturelle. Kanskje er det ikke her man først og fremst forventer å få tilgang til forskning om samiske forhold. Nettopp dette er en hovedgrunn til at vi ville lage dette temanummeret med artikler som kretser rundt temaet samer som urfolk i skole og samfunn.

Vi to som er redaktører for dette temanummeret, jobber henholdsvis på Senter for samiske studier (UIT) og Seksjon for flerkulturelle studier (OsloMet). Vi er slik representanter for nettopp dette spennet. Ikke desto mindre har vi, som gamle kjente, ved flere anledninger diskutert mulighetene for samarbeid og brobygging mellom våre felt - urfolksstudier, samisk forskning og flerkulturelle studier.

Dette nummeret rommer tre artikler som alle omhandler problemstillinger vedrørende samene som urfolk i dagens Norge - med blikk mot historie og nasjonsbygging, mot skole og storsamfunn, samt mot det internasjonale urfolkssamfunnet.

I den første av artiklene skriver Torjer A. Olsen og Bengt-Ove Andreassen, begge ved UiT Norges arktiske universitet, henholdsvis på Senter for samiske studier og Institutt for lærerutdanning og pedagogikk, om den generelle delen av læreplanene for den norske skolen fra 1974 til 2017. De analyserer hvordan samer, samiske forhold og ulike begreper for mangfold blir beskrevet i læreplanens mest politiske og ideologiske tekster. Olsen og Andreassen viser at de skiftende læreplanene gir uttrykk for skiftende politikk og samfunnsforhold. Økende innvandring fra andre deler av verden til Norge kommer fram gjennom begreper som «fremmedarbeidere», innvandrere og etniske minoriteter. Samene beskriver som «elever fra språkblandingsdistrikter», en etnisk minoritet i særstilling og som urfolk - 27 år etter at Norge som stat anerkjente samene som sådan. 
Kajsa Kemi Gjerpe, doktorgradsstudent i urfolksstudier og pedagogikk ved UiTs Senter for samiske studier, skriver om urfolk og utdanning i henholdsvis Norge og Aotearoa/New Zealand. Hun viser hvordan skole og utdanning er et viktig felt for både samer og maorier, og at $\mathrm{i}$ begge tilfeller finnes sterke bevegelser for å utvikle egne skoler. Samtidig er det en utfordring at flertallet av elevene går i majoritetsskolen. Dermed er det et behov for å styrke majoritetsskolens utdanning om urfolk og urfolks situasjon.

Lars Lien, historiker ved Senter for studier av Holocaust og livssynsminoriteter (HL-senteret), skriver om nasjonsbegrepet i samisk sammenheng. Med utgangpunkt i dagsaktuelle debatter om hvorvidt den offisielle flaggdagen i Norge 6. februar kan og bør omtales som «samefolkets dag» eller «samenes nasjonaldag», trekker han linjer bakover i historien. Han viser hvordan samisk nasjonalbevissthet vokste fram allerede på begynnelsen av 1900-tallet, som motsvar til den norske nasjonalismen i kjølvannet av unionsoppløsningen. Ifølge Lien er dette en viktig bakgrunn for å forstå anvendelsen av det samiske nasjonsbegrepet. En årsak til at det samiske nasjonsbegrepet i dag kan virke fremmed, og muligens også provoserende, er at denne delen av historien i stor grad har vært oversett.

\section{Litteratur}

Plesner, I. T., Brandal, N. \& Døving, C. A. (2017). Hvor like må vi være? Gamle minoriteter i det nye Norge. I N. Brandal, I. T. Plesner, I. T. \& C. A. Døving (Red.), Nasjonale minoriteter og urfolk i norsk politikk fra 1900 til 2016 (s. 13-25). Oslo: Cappelen Damm Akademisk.

Midtbøen, A. H. (2017). Innvandringshistorie som faghistorie: Kontroverser i norsk migrasjonsforskning. Nytt Norsk Tidsskrift, 34(02), 130-149. https://doi.org/10.18261/issn.1504-3053-2017-02-03

Røthing, Å. (2017). Mangfoldskompetanse. Perspektiver på undervisning i yrkesfag. Oslo: Cappelen Damm Akademisk. 